\title{
Клеточная биологuя
}

удк $577.21+577.152 .5$

С. В. Сторожкенко, Е. Н. ЈІиша, Ю. Ю. Глеба

\section{TPАНСФОРМАЦИЯ РАСТЕНИЙ NICOTIANA TABACUM ГЕНОМ ДНК-ТОПОИЗОМЕРАЗЫ II ТИПА DROSOPHILA MELANOGASTER}

\begin{abstract}
На основе бимарного вектора pвіп19 создана плазиидо pBin19/t2103. содержанцая структурный ген ДНК-топоизомеразы II типа D. melanogaster nod контролен 35 S-nponoтора вируса мозанки иветной капусты. Конструкиия перенесена в растения табака $N$. tahacum SR-1 c nомои孔ьо опосредованной аеробактериями трансрормации по мето-

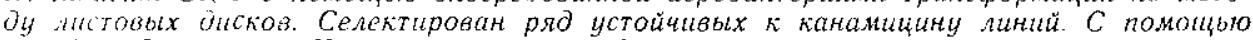
м'тоіов Саузерн- "Н Нозерн-блотинг-гибридизаиий показана интеграиия аена в состан 'еноной ДНК и его экспрессия на уровне транскрипиии. $В$ геноме табака обнаружена последовательность, гибридизующцаяя с фрагментом сена ДНК-топонзомерази $I I$ брозодиль. Эта последовательность, возможно, является геком растительноӥ ДI/K-топоизомеразы HI TIna.
\end{abstract}

Введение. ДНК-топоизомеразы - особая группа ферментов, которые посредством введения обратимых двухцепочечных (топоизомеразы II типа) или одноцепочечных (топоизомеразы I типа) разрывов способны нидуцировать в молекулах ДНК топологические переходы, такне как суперспирализация - релаксация, катенирование - декатенирование, заузливание - разузливание. Как правило, подобные псреходы явпяются следствием разрешения топологических проблем, возпикающи при всех естественных процессах клеточного метаболизма ДНК, требуюпих расплетения цепей. Следовательно, ДНК-топоизомеразы участвуют в процессах репликации, транскрипции, транспозиции, рекомбинации и некоторых других [1]. Кроме того, ДНК-топоизомеразы сами способны нндуцировать «незаконную» рекомбинацию in vitro и in vivo [2]. С другой стороны, они повышают стабильность генома, релаксируя отрицателыне супервитки [3] .

Несмотря на то, что каталитические свойства ДНК-топоизомераз достаточно хорошо изучены in vitro [4], роль их in vivo остается, в основном, предметом различного рода спекуляций и умозаключенпй. Это касается, в частности, участия ДНК-топонзомераз в рсгуляции экспресси генов. Так как степень суперспирализации влияет на уровень транскрипцин многих генов [1], то топоизомеразы, вероятно, способны модулировать экспрессию генов, изменяя степень суперспирализации ДНК. При этом экспрессия генов самих топоизомераз должна быть строго контролируемой.

Растения являются уникальными организмами, поскольку сопстают в своей клетке три генетические системы: ядра, хлоропластов и мигохондрнй. Наличие таких относительно независимых систем предпо. агаст существование трех соответствующих пулов ДНК-топоизомсраз. Часть нз них довольно хорошо охарактеризована [5-8]. О генах растительных топоизомераз информация пока отсутствует. Извсстно, однако, пто активность топоизомеразы II типа возрастает в быстрорастушцх недифференцированных тканях и существенно спижается в тканях дифферечцированных [9]. Это позволяет предположить, цто экспрсссня генов топонзомераз является регулируемой.

С: С. В. Стороженко, Е. И. Шиша, Ю. Ю. Глеба, 1993 
Учитывая все возрастающий интерес к вопросам участия ДНК-топонзомераз в регуляции экспрессии генов, а также к получению и изучению трансгенных растений, экспрессирующих ДНК-модифицирующне белки, мы решнли создать растения с экспрессией чужеродной ДНК-топоизомеразы II типа. Исследование последствий такой конститутивной экспрессии на фоне регулируємой экспрессии генов собственных топонзомераз, возможно, прольет свет на некоторые аспекты функцнонирования этнх ферментов in vivo, их участия в процессах регуляции экспрессии генов, «незаконной» рекомбинации.

материалы и методы. Плазмиды и бактери альны е ш т м м ы. Плазмида $p G F c-1$ [10], содержашая кДНК топоизомсразы II типа дрозофилы, любезно предоставлена д-ром Т. Хсиехом (Мед. центр Ун-та Штата Северная Каролина, США). Для постановки гена под контроль 35S-промотора вируса мозаики цветной капусты использовали кассету экспрессии pRT103 [11].

Bо всех процепурах по клонированию применяли штамм Escherichia coli JM101.

B качестве вскторной системы для трансформации растений табака $N$. tabacum SR-1 был избран бинарныи вектор pBin19 и штамм агробактерий Agrobacterium iumefaciens C58C1 (pMP90) [12].

В ыд ление плазмидной ДНК и процедуры клопl р р в а н и П. Плазмидную ДНК выделяли по методу шелочного ли3rсa [13]. Во всех гроцедурах клонирования использовали эндонуклеазд рсстрикции и Т4-ДНК-лигазу фирмы «Ферментас» (Литва). Реакпии расшепления ДНК рестриктазами и лигирования проводили, как onисано в [13], с учетом рекомендаций фирмы-изготовителя ферментов.

Фрагменты ДІК после фракционирования в $0,8 \%-м$ агарозном гое выдсляли с иомощью электроэлюции [13].

Трансформацию $E$. coli осуществляли по методу, предложенному Cumanicom [14].

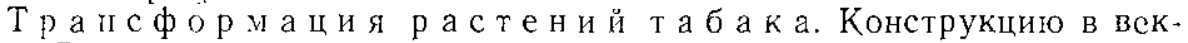
rope pBin19 иоби.тнзовали в агробактерии посредством триродительского скрешивания [14]. В качестве штамма-помощника был избран инамм E. coli IIB101, несуший плазмнду $p R K 2013$.

Трансформацию растений проводили по методу листовых дисков [15]. Растсния табака вырацива.ти в стерильных условиях на среде MC [16]. Листья двухмесячных растений инкубироваэи 15 мин в ночної кутьтуре агробактерий и помещали па чашки с регенерапионыой сроної (миперашьная основа среды $\mathrm{MC}$ с добавленисм 1 мг/л БАП и $0.1 \mathrm{~m} / \mathrm{s}$ НУҚ) па двое суток. Затем листовые диски отмывали в теџмијс 5 мин в жидкой MC с добавлением цефотаксима до концентрашин 500 мг/л, слсгка подсушивали с помощью фильтровальной бумаги If помсшали на селективнуло регенерационную среду того же состава с :обав.тенисм 500 мг/л цефотаксима и 100 мг/л канамицина до появ$\because$ пня побегов. Регенеранты переносили на среду $\mathrm{MC}$ с 500 мг/. псфотаксима и 100 мг/л канамицина для укоренения. Укорснившнсея растени пересаживали в почву и использовачи для дальнсйmего анализа.

В ыд слени с ну к л сл н о вы х ки слот. Суммарную ДНҚ из растсний выделяли с помошью СТАВ [17]; суммарную раститсльную PIК -- по мстоду, прсдложенному Кирком и соавт. [18].

С аузери-и Нозерн-блотинг-гибридизации. Для гибрнднзации применяни ней.тоновые фильтры Сартолон («Sartorius», ФРГ).

Гсль, получниый послс электрофореза рестрицированной ДНК, обрабатыва.ти $0,25 \mathrm{M} \mathrm{HCl}$ в течение 15 мин и $0,5 \mathrm{M} \mathrm{NaOH}$ в теченис 30 мни (материал переносили в 25 м $\mathrm{Na-фосфатном} \mathrm{буфере,} \mathrm{pI} 7,2$, го тенене ночи).

Элсктрофорез РНК проводпли в $1 \%$-й агарозе с добавленисм форmitimiternдa ло концентрации $1,1 \mathrm{M}$ в 10 мM Na-фосфатном буфере, pl $6,5$. Перенос осушествлял! в 10ХSSC буфере. 
Қак Саузерн-, так и Нозерн-гибридизации вели в $0,5 \mathrm{M}$ Na-фосфатном буфере, $\mathrm{pH} 7,2,7 \%$ DS-Na, 1 мМ ЭДТА в течение почा. Фи'Il, тры отмывали 4 раза по 1 ч в буфсре, содержащем 40 мM Na-фосфат, pH 7,2, $1 \%$ DS-Na, 1 мМ ЭДТА при $65^{\circ} \mathrm{C}[19]$.

В качестве зонда иснользовали фрагмснты ДНК, мсчепиы з2р по мстоду рассеянной затравки [20] до уделынй актлвности $10^{9}$ имп $X$

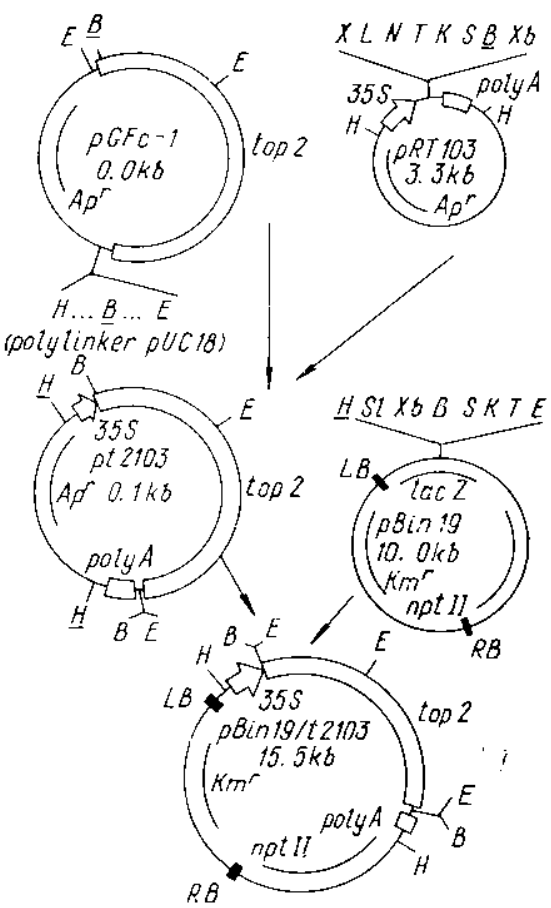
Хмин ${ }^{-1} \cdot \mathrm{MKг}^{-1}$ с помощью пабора Random Primed DNA Labelling Kit ( $\ll \mathrm{Bo}-$ chringer Mannheim», $\Phi P \Gamma)$.

Результаты и обсуждение. Схема создания конструкции для эксгрессип структурного гена ДНК-топонзомеразы II типа в клетках растений прсдставлена на рис. 1. Структуриы ген top2 вырезали из полазмиды $p G F C^{-1}$ по

Рис. 1. Схема получения рекомбинантной плазмиды pBin 19/12103. Подеркпуты сайты, по которым проводили клонирование: $B-B a m H I . E-E c o R I, H-H i n d I I, L-B a l l$, $N-N c o I, K-K p n I, S-S m a I, S I-S a l I, T-S s t I, X-X h o i, X b-X b I$

Рис, 2. Блотинг-гцбридизащия по Саузерну расщепленюой HindII суммарной ДНК трансформнрованных линий табака: 1 - ДНК нетрансформированного растения; 2 -.$6-$ ДНК линий $2,15,21,19,23$ соответственно. Стрелкой өбознаси фрагмент (5,5 тыс. п. и.), содержащий перенесенный ген с регуляторными элемеитами

сайту BämHI. При таком варианте ген содержит полную 3'-петрапелируемую область и имеет делецю 28 ампноклслотных остатков на 5'-конце. Каким образом эта делсция влияет на активность фермена, пока нсясно. Проводятся эксперименты по экспрессин данного фрагмента гена в $E$. coli с целью выяснения сго каталитичсскых своінетв. Следует также заметить, что при выделении топоизомеразы II 113 эмбрионов дрозофилы обнаруживастся ряд протеолитичсских фрагментов, обладающих ферментативной активностью [21].

Далее, BamHI-фрагмент гена клонировали в BamHI-сайте кассеты экспрессии pRT103, при этом рамка считывапия собственного стартового кодона кассеты, находящегося в составе $N$ col-сайта, ı рамка считывания гена совпадают. Полученная таким образом плазмияа pt2103 содсржит неполный ген ДНК-тоноизомеразы II дрозофны под коптролсм 35S-промотора вируса мозаики цветной капусты и фитанкрована на $3^{\prime}$-конце сигналом полиаденилирования того же вируса. Так как кассста экспрессии содержит вместе с собствснным ATG-ко;юном консенсусную последовательность сайта связывания малой субчастицы эукариотичсской рибосомы, то можно ожидать эффективной трансіяции гена.

Для введения кассеты экспрессии в растснис испопьзовали бщнарный вектор pBin19, в составе которого по сайту Hindlll к.тонироваілl 
гсн с рсгуляторными элементами, вырезанный из плазмиды pt2103 по romy жс сайту.

Выленснная плазмида $p \operatorname{Bin19/i2103}$ была мобилизована в штамм агробактерий с помощью триродительского скрещивания. Из клонов, устойшнвых к канамицину к рифампицину, выделяли плазмиду и провсряли ее с помощью рестрикционного анализа (данные не пред(тависны) .

I loлученным штаммом агробактерий инфицировали листовые диски табака. Селектированы 39 клонов, устойчивых к канамицину в концентрация 100-200 мкг/мл. Нз клонов регенерировали нормальные растспия с несколько замедлснным ростом по сравнению с нетрансформированными контрольными растениями. Выводы о нормальном нын аномальном фенотипе пока делать рано, так как для этого растепня должиы пройти все стадии жизненного цикла в почве. Изучснию фенотипа трансформированных растсний можно посвятить отдельное nссленован.

ل1з сслектированных растительных клонов произвольным образом отобрахи пять для проверки их трансгенности с помошью блотинг-гибрндазацин но Саузерну. Суммарную раститсльную ДНК расщепляли эндопуклеазой рсстрикции Hindll,, фракционировали электрофорезом в агарозном гелс, персносили на нейлоновые фильтры и гибридизовали с меченым BamHI-фрагментом плазмиды $p G F c-1$ (5,5 тыс. п. н.), содсржацим структурный ген топоизомеразы. Результаты представлены ша pнс. 2. Hнтерссно отметить, что во всех пяти клонах присутствует гибргцизационый сигнал, соответствующий фрагменту размером примерно 6 тыс. гі. н., это касается и контрольного нетрансформированного растения. Мы полагасм, что данный сигнал-это результат гибpидизацил зонда с собственным геном растительной ДНК-топопзомеразы II типа, так как нзвестно, что все клонированные гены топонзомсраз II тина отличатся значитсльной степенью гомологии [22]. Ннформация о растительных генах ДНК-топоизомсраз пока отсутствует. Два киона (19-й и 23-й), однако, содержат дополнительную полосу гибрпдизапи, отвечающую фрагменту необходимой длины $-5,5$ тыс. п. н. Чтобы убедиться, что данная полоса действительно соотвстствует искомому фрагменту, растительную ДНК расщепляли рсстриктазой EcoRl н полвергали гибриднзацик в аналогичных условиях (рис. 3). lla лорожках, соответствующих 23-му и 19-му клонам, видны фрагменты размерами 3,2 и 2,1 тыс. п. н., которые возникли вследсствис расиспления введениого гена рестриктазой EcoRI. В других клонах н контроле даные сигналы отсутствуют. Это свидетельствует о том, что осталыне кионы пе являются трансгенымн. И в этом случае на всех дорожках видны сигналы, отвечаюшие собственной растительной посіледоватеныності, гибридизующейся с зондом.

Д.я изучення экспресспи на уровне транскрипция из 19-го и 23-го к.тоно выдсляли суммарную РІІК. Затем РНК разделяли элсктрофо-

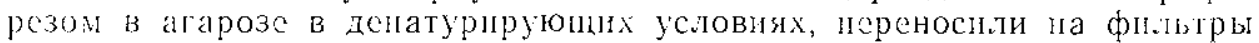
п гибрнднзованп с тем же зондом, тто и в случае блотинг-гибридизаm.1? по Саузерпу. Рсзультаты Іозерн-блотинга показаны па рнс. 4. Гибрпдизапноние сигналы на дорожках, соответствуюших 19-му н 23-му клолам, :о всличне отвечают ожидаемому размеру мPIIK 4.7 тыс. п. п. РІ !K нетрансформированиого растения с зондом не гнбpндызуется. В сы : зи с этнм уместно рассмотреть вышеупомянутый факт, касаюшиїся геп мной послсдоватсльпости, гибридизуюшсйся с зопџм. Еспи прсцолож ть, что данная нослсдоватсльность является собственпым геном ДI:-топоизомеразы II типа, то в итоге его экспрессии

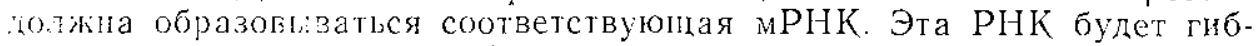
рндизоватіся с индом с большсй пнтенсивностью, чем ДНК, встедствие большсй с :бильності PIIK-ДНК гибридов. В пашем случас такой гибрндизаци: не наблодалось, что может быть рсзультатом .пбо очен, пнкого ур: әня экспрессии, тибо вообще отсутствия таковой. 13вестио, что акти:.ость растите:іной топоизомеразы II возрастает при- 
мерно в 2,5 раза в недифференцированных активно пролифериругщих тканях и существенно снижается в тканях дифференцированных [9]. В качестве одного из гипотетических механизмов регуляции активности топоизомеразы II типа ранее обсуждалось фосфорилированне фсрмента протеинкиназой C у губки Geodia [23]. Вторым механизмом, объясняющим колебания активности топоизомеразы, может быть регулируемая экспрессня гена, кодирующего фермент, причем налнтие последнего механизма отнюдь не отрицает существования предыдущего. В нашем случае РНК выделяли нз листьев, и можно допустить, что
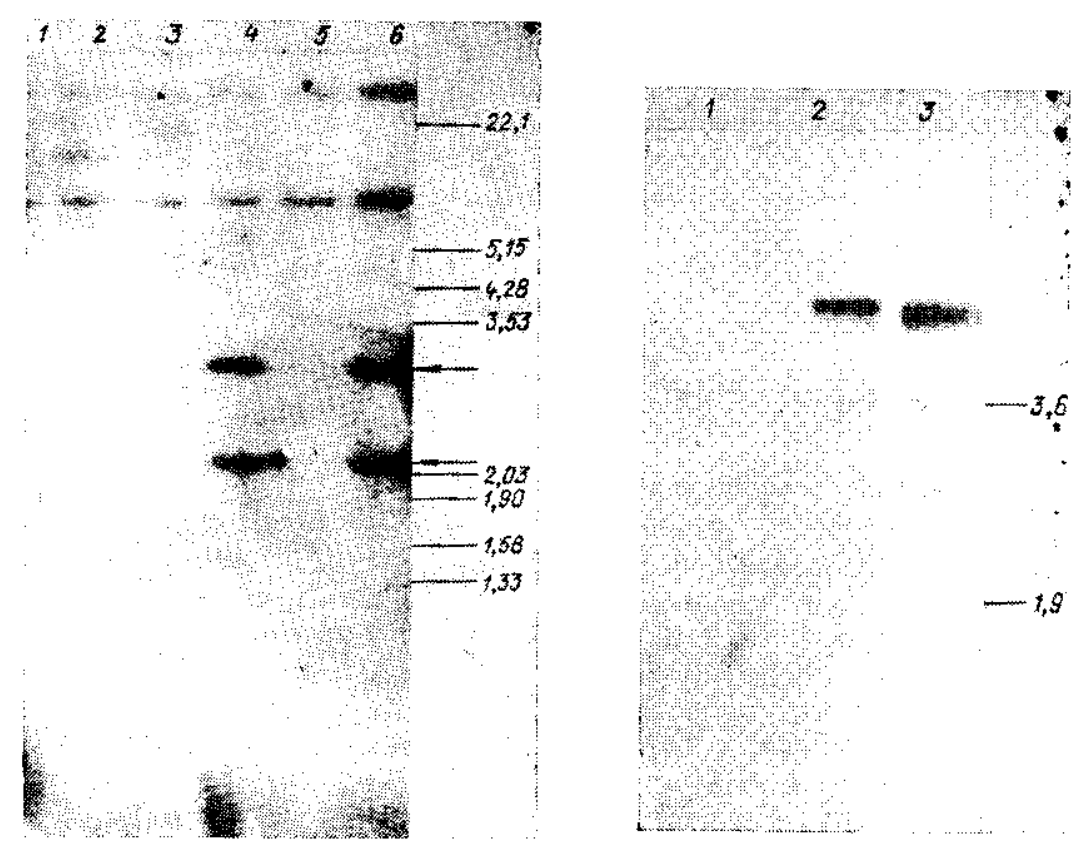

Рнс. 3. Саузерп-блотинг-гибридизация EcoRI-персвара суммарной ДНК трансформированных : иний табака: 1 - ДНК нетрансформированного растения; $2-6-$ линил $2,15$. $19,21,23$ соответственно. Стрелками обозначены фрагменты введенного гена размером 3,2 и 2,1 тыс. п. н.

Рис. 4. Нозерн-блотинг-гибридизация суммарной РНК трансгенных линий табака: 1 -PHK нетрансформированного растения: 2, 3- PHK линий 19, 23 соответствению

ген экспрессируется на очень низком уровне, хотя столь незпачитель. ная экспрессия представляется маловероятной. В любом случае, данный факт кажется любопытным и, на наш взгляд, требует болес детального изучения.

В настоящее время исследуются экспрессия на уровне трансляцин, определение биологической активности продукта экспрессии введенного гена, а также фенотищические эффекты экспрессии. Результаты этих исследований будут опубликованы несколько позже.

Авторы полагают, что полученные трансгенные растения являются интересным материалом для исследования свойств ДНК-тогоизомеразы II типа в гетерологичном для нее окружении, ее участия в процессах регуляции экспрессии генов и клеточного метаболизма ДНК В целом.

Summary. A plasmid pBin19/t2103 based on a binary vector $p$ Bin19 has been constructed. The plasmid carryes the structural gene coding for DNA topoisomerase II type from $D$. melanogaster under control of $35 \mathrm{~S}$ promoter from cauliflower mosaic virus. The construction was introduced into tobacco plants $N$. tabacum SR-1 using $A$. lumefaciens-mediated transformation. An integration of the gene in plant genome and its expression on transcriptional level have been shown. A sequence from tobacco genome was found to hybridized with the fragment of the topoisomerase 11 structural gene. It seems to be plant DNA topoisomerase II type gene. 


\section{СПИСОК ЛИТЕРАТУРЫ}

1. Vosberg H. P. DNA topoisomerases: enzymes that control DNA conformation //Curr. Top. Microbiol. and Immunol.-1985-114, N 1.- P. 19-102.

2. Ikeda $H$. DNA topoisomerase-mediated illegitimate recombination // DNA topolugy and its biological effects. - New York: Cold Spring Harbor Lab., 1990.- P. 341-359.

3. Wang $J . C$., Caron P. R., Kim R. A. The role of DNA topoisomerases in recombination and genome stability: a double-edged sword? //Cell - 1990.-62, N 3.- P. 403-406.

4. Ocheroff $N$. Biochenical basis for the interactions of type I and type II topoisomerases with DNA// Pharm. Ther.-1989.-41, N 2.-P. 223-241.

5. Fukata $H$., Fukasava $H$. Isolation and partial characterization of two distinct DNA topoisomerases from Cauliflower inflorescence//J. Biochem.-1982.-91, N 2. P. $1337-1342$

6. Руденко Г. Н. Выделение и характеристика двух различных ДНҚ-топоизомераз I тнпа из листьев Pisum sativum // Молекуляр. бнология.-1991._-25, № 5:-C. 1316.

7. Руденко Г. Н. Растительная ДНК-топоизомераза II типа: выделение, характеристика и свойства // Там же.-№ 4.-С. $1125-1135$.

8. Cитайло Л. А. Хлоропластная ДНК-топоизомераза I типа из листьев гороха // Биопоілимерги и клетка.-1991.- 7, № 4.-С. 97-103.

9. Carballo M., Gine R., Sanlos M., Puigdomenech K. Characterization of topoisomerases $I$ and Il activities in nuclear exiracts during callogenesis in immature embrios in Zea mays // Plant Mol. Biol. - 1991.- 16, N 1.-P. 59-70.

10. Volan J. M., Lee M. P., Wyckoff E., Hsieh T. Isolation and characterization of the genc encoding Drosophila DNA topoisomerase Ii // Proc. Nat. Acad. Sci. USA._1986.83. N 11-P.3664-3668.

11. Töpfer R., Malzeit V.. Gronenborn B. et al. A set of plant expression vectors for transcriptional and translational fusions // Nucl. Acids Res.-1987.-15, N 14.- P. 5890.

12. Koncz $C$., Schell J. The promoter of Tl-DNA gene 5 controls the tissues-specilic expression of chimeric genes carried by a novel type of Agrobacteriam binary vector // Mol. alld Gen. Genct.-1986.-204, N 3.-P. 383-396.

13. Huнtaти $T .$, ррич E. $\phi .$, Сэморук Дж. Методы генетической инженерии. Молекупнирие кионирования - М. : Мир, 1984.-521 с

14. Гоosep Д. К.лонирование ДНК.- М. : Мир, 1988.-538 с.

15. Horsch R. B. Fry J. E. Hoffman A. L. et al. A simpie and general method for twansferring genes into plants// Science-1985,-227, N 4691.-P. 1229-1231.

li, Murachige $T$. Skoog $F$. $A$ revised medium for rapid growth and bioassays with to bacco tisste culture // Physiol. Plant.-1962.-15, N 4.-P. 473-497.

17. Murray M. J., Thompson W. E. Rapid isolation of high molecular weight DNA// Nuci. Acids Res.- 1980-8, N 19.- P. 4321-4325.

18. Kirk $M . M$. Kirk $L . D$. Translation regulation of protein synthesis, in response to Iight at a critical stage of Volvox development // Cell.-1985.-41, N 2.- P. 419-428.

19. Chuch G. M., Gilbert W. Genomic sequencing // Proc. Nat. Acad. Sci. USA.- 1984.-$81, \mathrm{~N} 7 \ldots$. P. 1991-1995.

20. Veinberg A. P.. Volgenstein B. A technique for radiolabelling DNA restriction fragments to high specific activity// Anal. Biochem.-1984.-137, N 5.- P. 266-267.

21. Hsieh T. Purification and properties of type II DNA topoisomerase from embryos of D. melanogaster // Meth. Enzymol-1983.-100.- P. 161-170.

22. Wang J. C. Recent studies of DNA topoisomerases // Biochim. et biophys. acta,- 1987.$909, \mathrm{~N}_{1}-\mathrm{-}$ - P. $1-9$.

23. Rottman M., Schroder H. C., Gramasov M. et al. Specific phosphorilation of proteins in pore complex laminal aggregation factor and phorbol ester// EMBO J.- 1987.-6. N 13.- P. 3939-3944.

Ин-т клеточ. биолюгин и генет. инженерии АН Украины, Киев Получено 21.07.02

уцК 577.39

\section{В. И. Древаль}

\section{ПОСТРАДИАЦИОННЫЕ ИЗМЕНЕНИЯ СТРУКТУРЫ ЛИПИДОВ И БЕЛКОВ ПЛАЗМАТИЧЕСКИХ МЕМБРАН ТИМОЦИТОВ}

Кроєс облучали в дозах 1,5; 4,0; 7.0 и 10,0 Гр. Спустя 1, 8, 15, 22 и 30 сут в тимоинтах определяли связывание 1-анилинонафталин-8-сульфоната, вязкость липидов иконстанту Штерна-Фольмера для белков плазматияеских мембран. Установлено, что для процесса пострадиачионных изменений характерна фазовая периодичность структурных перестроек плазматических мембран.

Введение. В настоящее время успешно развиваются исследования, направленные на расшифровку механизма интерфазной гибели клеток, лежащей в основе клеточного опустошения кроветворной системы при

(C) В. И. Древаль, 1993

ISSN 0233-7657. БИОПОЛИМЕРЫ И КЛЕТКА. 1993. Т. 9. N 1 